\title{
DESCARTES-EN ONTO-METODOA: ZIENTZIAREN FINKATZEA
}

\author{
Juan Ramón Makuso
}

"Oraindik badauzkagu, egia da, kongresu filosofikoak, filosofosk biltzen dira; baisa, tamalez, ez filosofiak."

(E. Husser])

Husserl- en burutazio lau ezin hobeto datorkigu kongresu honetan lausnarketa bat egiteko, hitz horick sakonean zer adierazten duten sakontzeko. Eta hitz horiek bere Kartesiar Mfedi-tazioak liburuan esanak dira. Beraz protagonista René Descartes da.

Husserl-ek testu inguru konkretu batean egin zuen hausnarketa hori, Descartes-ek zientziarako, filosofiarako zein proiektu zeukan aztertzerakoan, hain zuzen ere. Hau egin ondotik, Husserl-ek filosofoei uzten die txanda. Eta egia da, zer egiten dute filosofoek? Ez ote dira sasi-kritikatan erortzen ari, beren ikerketatan benetako hausnarketarik, BENETAKO BAT, proiektatu gabe?. Egin dezagun bada Descartes-ek bere gaztaroan egin zuena, ausartu gaitezen, huskeriak utzi eta berraztertu dezagun benetan zer egiten dugun filosofiarekin.

Descartes-ek bere gaztaroan ikasketa guztiak alde batera utzi eta bere bizitzari beste proiekzio bat eman zion, bere buruarekiko iraultza bat zekarren ekintza bati ckin zion. Interesgarria benetan Descartes-en apustua: zegoena irauli eta proiektu berri bati hasiera eman, pertsona mailan bederen eta hau ez da izango azkenekoa. Descartes benetako iraultzailetzat jo daiteke, izan ere, bere biogralia horrelako xehetasunez betea dago. Bere proiektuaren ardatzak filosofiaren historian urrats berri bat ekarriko baitu. Cogitoa, zientziaren eta tilosoliaren ardatza izango da aurrerantzean eta hau ez du inork zalantzen jartzen. Baina bere aplikazioa bestela ulertu da. Begira bestela zer gertatu den zientziaren dibertsifikazioarekin. Descartes-en asmoak zientziarako eta orolhar pentsamenduarako bat bera ziren: cogitoa edozein proiekturen zutabe, oinarri izatea. Hori izan baita bere nabaritasuna, aurkitu nahi zuen zientzarako batasuna, eta bere metodoaren printzipioa. Hortik aurrera gertatutakoak ez dira izan Descartes-en akatsak, baizik eta kanpotikako arduragabekeria. Azken finean cogito-ak eragindakoak, historian zehar banako ezberdinek utzi duten ondarea izan dira, filosofiak, eta ez filosofia.

Nahi al zuen bada, Descartes-ek bere proiektu zientifikorako gero gertatu den zatiketarik? Inondik ere ez. Berak, era aristoteliar' batean bildu nahi du bere proiektuan maisuak esan zuena. Filosofia jakintzatzat, gizakiaren ilarduera nagusitzat. Beraz, nora garamatza Descartesen onto-metodoak?

Descartes-ek, izakiaren eta pentsamenduaren artean ez du inongo marrarik, liesirik, eraikitzen. Horretan Parmenideren? lekukoa hartzen du: pentsatzeak ez dakar ondoriotzat izatea, baizik bata bestearen baitan txertaturik dago. Txertatze honck euskarri bat dakarkio Descartes-en metodoari, bestela ez luke cogitoa bere proicktoaren nabaritasun matematiko antzera hartuko. Zer dela eta matematikoa? Descartes-ek ez du proiektu antzurik nahi, ez du errepikatu nahi metodoaren inguruan garaian gertatzen ari den eztabaida. Matematika eredu da, baima ZIENTZIAREN $A$ ? ala cogito-aren erreferentzia galdua gelditzen zaion erreferentzia konkretu batena, “zientzia partikularrena? Ez, Descartes-ek bere proicktuarentzat

I Aristotele, Mtofisika, 1, 2

2 Parmenide, Procmioa, (Fr. 3) Filosolo presokratikoak, G.S. Kirk y J.E. Ravell, 377. orr., Gredos. 
metodo zulur bat nahi du, eta honekin batera, ZIENTZIARENTZAT baliagarri izango den nabaritasun bat. Diskurtso bakartiar batentzat izango ez den nabaritasun bat, edonork harekin lan egin ahal izango duena. Ez da izango dibertsifikaziorik. Eta bere egitamua hortik abiatuko da. Eta datu hau Descartes gaztearen ihardueran sostengatzen da. ${ }^{3}$

Jakin behar da Descartes-en iharduera ildo horretatik abiatzen dela. Esan daiteke Descartes-ek, bere iharduera dela medio, berpizkundeko gizon- eredua betetzen duela, baina hori ez da horrela. Berpizkundearen izpiritua lotuagoa legoke zientziaren dibertsitikazioarekin, esparru ezberdinek euren artean inongo loturarik ez dutelarik. Descartes ez doa eredu horrekin. Bere helburua errealitatearen ezagutza bideratuko lukeen osotasunezko jakintza lortzea litzateke. Berriro ere antzeman daiteke aristoteliar kutsua.(Ezin ahantz dezakegu bere hasierako formakuntza). ${ }^{4}$

Descartes-ek bere proiektoa puntu jakin batetik abiatzen du. Lelen esan dugu bere gaztaroan eskuartean zeukan guztia alde batera uzten duela, eta bizi berri bati ekiten diola. Gauza bera egiten du bere proiektu fillosofikoa eraikitzen lasten denean. Uste du, bide berriari ekiteko, bere formazioan eragina izan duen guztia alde batera utzi behar duela, eta hori elementu berri bat eraikiz egiten du: zalantza. Zalantza Descartes-entzat bere metodoa eraikitzeko elementu metodiko bat izango da, eraikitze honetan guztia jarriko baitu zalantzan. Zalantza ez da izango tresna eszeptiko bat -honek Descartes-en neutraltasuna ere frogatzen du-. Descartes-en apustua beraz sistema bat eraikitzean datza, hartara bere iharduera frogez betea dago.

Zalantza hau beraz. Descartes-entzat bide bat izango da, bide honek erakutsiko dio historian zebar egin diren akatsak non dauden, eta bera, akats horietatik ihesi dabil. Beraz, zalantza, metodikoaz gain, erakusle ere izango da Descartes-entzat. Eta hau guztia zertarako? Zientziaren finkatzea lortzeko.

Zientzia finkatzea nola lortu? Descartes-en asmoak ez dira nolanahikoak. Garai hartan, hasi zen jada zientziaren dibertsifikazioa, zatiketa gertatzen. Aristotele-ren filosofia-eraikuntza bertan behera geratzeko arriskuan dago —unibertsoaren ikusmoldeari hori gernatuko zaio iraultza zientifikoarekin-, eta ematen ari diren pausuak itxura txarra dute, benetako zientzia bat eraikitzekotan. Azken finean "filosofiak" eraikitzea da egiten ari dena eta benetazko filosolia-korpus bati muzin egiten zaio. Agian, ez delako onartu nahi zaila dela benetan iharduera hori, eta sasi-diskurtso filosofikoak eraikitzen dira nolanahi. ${ }^{5}$

Iraultza zientifikoak beraz, badu aurrerapausorik, baina akits bat ere bai: gizakien kontzientziak dibertsifikazioaren bidetik bideratzen ditu, zatiketa nagusitzen da. Metodo baten beharra azpimarratzen da, matematikak zientziaren eredu bilakatzen dira -arestian aipatu printzipio aristoteliarra ahantziz-. Baina, horrela zientzia finkatzen al dugu, ordea? Argi dago metodo bilakaera horretan, iraultza zientifikoak eman duen aurrerapausua haundia izan dela baina, Descartes-ek, dena aztertu nahi du, zientziarentzat edozein iharduera zientifikorako baliagarria izango den metodo integratzailerik ez dela oraino aurkitu ikusten duclako. Eta bilakacra honetan Descartes-ek bere nabaritasun nagusia, bere filosofiaren iraultza, aurkezten du: guztiok ezagutzen dugun printzipioa - beretzat lehena-:

... Ets ikusirik egia hau : pentsatzen dut, beraz, banaiz, lain zulurra eta sendoa zzla (...), lelaenengo printzipiotzat onar nezaleela irizzi nion. ${ }^{6}$

3 Descartes, René, El mundo. Tratado de la luz, Salvio Turró, Estudio introductorio, 9. orr., Anthropos.

4 Gilson Etienne: Entes sur le rôle de la pensée médieivale dans la formation du sistème cartésien, rol. xill de Éludes de philosophie médiérale. Paris: Vrin, 1930.

5 Galileo, El essscriador, 6.

6 Descartes, René, Discours de la méthode: Introduction et notes, E.Gilson, Daris: Vrin, 1979, 89. orr. 
Eta Descartes-entzat printzipio hau jakintzaren zutabea izango da. Jakintza, filosofia eta zientzia. Eta hau guztia bere hasierako ihardueran azpimarratzen du: armazoia azterketak egiteko elementu gisa; badira, ordea, beste batzuk, hala nola, esperientzia:

Honela, esperientziei dagokienez, ezagutzan zenbat eta gehiago aurseratu orduan eta beharrezkoagoak direla, ohartzen nintzen. ${ }^{7}$

Hau horrela ikusirik, nork jar lezake zalantzan Deskartes-en asmo xumea, nola diren, zientziaren finkatzea ezer baztertu gabe, ezagutzaren lorpena, ezagutza, eta ez ezagutza partikular bat? Aurrerago ere ikusiko dugu adibide gehiago.

Zientzia, beraz, ezin da eraiki zatiketa oinarritzat bezala hartuz. Eta are gutxiago Descartes-en proiektoa aztertzen baldin badugu.

Descartes-en onto-metodoak, izatea du oinarri, ez du erreparatzen izaki partikular baten ihardueran, izaki horrek hautatu egiten baitu, tta hautaketa horretan, zientziari dagokionez, euskarri guztiak kontuan hartuz eraiki dezake, eta honek ez du esan nahi eraikitze horrek bide batetik edo bestetik joan behar duenik, lortu nahi duguna, Descartes-ek behintzat, zientziarentzako metodo bat baita:

Orgi juzkatzeko ahalmena eta egia dena faltsua denetik ongi bereiztea, "sena ona" edo "arrazoia" deritzoguna, izatez gizon guztietan berdintsua da; beraz gure iritzien dibertsitatea ez dator batzuk besteak baino arrazionalagoak izatetik, baizik eta gure pentsamenduak bide ezberdinetatik bideratzen ditugula, eta ez ditugu gauza berak kontuan. Ez da nahikon, benetan, adimen on bat izatea: garmantzitsuena ongi aplikatzea da. ${ }^{8}$

Eta metodo honek zientzia guztien batasunerako baliogarria beharko du izan. Eta honek beste datu bat agertzen du Descartes-engan: bere pentsamenduan ez dago eraldaketa haundirik -alde batera edo bestera apostu egitea, kampotik bultzatu zaiona: arrazionalista-enpiristabaizik, eta ideia bat eta lan bat burutzeko esfortzu haundia. Eta hau guztia Descartes-ek metafora oso polit batekin adieraziko digu Diskurtsoan:

Arkitekto bakar batek hasi eta bukatu dituen eraikinak politagoak izaten dira bestek zaharberritu nahi izan dituztenak baino, horretarako beste eginkizunetarako eraikiak izan ziren hormez baliatuz. ${ }^{9}$

Garniko jakinduria guztiak, zer adierazten digu? Iraultza zientifikoak hasitako zatiketak, zientziaren aurpegi zatigarriena aurkezten digu: ez dago inongo batasunik bere eraikuntzan eta horregatik ekiten dio Descartes-ek bere metodo berri horri; horrekin gorpuztuko du zientziak behar duen batasuna eta Iorrekin batera etorriko da zientziaren finkatzea.

Filosofia guztia zulaitz bat bezalakoa da, bere susiraiak metafisika dira, fisika enborra da, eta enbor horretatik ateratzen diren adaskak gainontzeko zientzia guztiak dira, hiru garrantzitsutara murriz daitezkeclarik: medikuntza, mekanika eta morala. Moralik perfektuena eta gorenena san nahi dut, beste zientziell osotasunezko ezagutza aurresuposstzean, jakinduriaren azken maila dena. 10

7 Op. cit. 130 orr.

8 Op. cit., 44 orr.

9 Op. cit. 59 orr.

10 Descantes, Rend, Printzipioak, itzultzaileari gutuns. 
Hona hemen filosofia, hasierako gizonek ulertzen zuten moduan. Gizonok, harridura sortu zenean ckin genion filosofatzeari, "l eta kasu honetan ezjakintasunak sortzen du harridura, baina ezjakintasun orokor batek ez gauza konkretuck. Beraz jakintza, ezagutzaren azken fundamentoa izango da. Filosofia eta zientzia ezin dira, beraz, banatu, edo behintzat ia ezinezkoa da banatzen. Horregatik gaur egun "zientziak" deitzen ditugunak, jakintza bakar bateko parte ziren, "filosofia" izenekoarenak. Aristotelek lehen filosofia deitzen zion. Zentzu honetan ulertu behar dugu Descartes-en aurreko testua.

Baina ikusi dugu iraultza zientifikoak zer egin zuen: zientzia filosofiatik banatu egin zen. Orain zientzia, filosofiarekiko gauza ezberdintzat agertzen zaigu. Bere ikerkuntza maila fenomenoetara mugatzen da, ez ditu zergatiak aztertzen.

Egoera honekin aurkitzen da Descartes eta bere iharduera ez dator bat garaiarekin. Berak, behin eta berriro aipatzen ari gara, ez du baztertzen bide bakar bat eraiki behar denik, are gehiago, horretan saiatuko da. Eta Metodoaren diskurısoa idazten duenean ez du idazten Metodoa bera bakarrik, baizik eta benetako zientzia-iharduera baten barnean, testu hau Geometria, Meteorns-ak eta Dióptrikin-rekin batera, korpus berean jdazten ditu. Hau gauza jakina da, hainbat ikerketatan agertzen da behintzat, baina hemen beste datu bat azaldu nahi genuke, agian ez delako hain ezaguna izango eta benetan Descartes-ek zientziarentzako dituen benetako asmoak agertzen dituelako.

Descartes, geometrialari gisa burutzen dituen ikerketengatik, ezin dugu baztertu metodoaren ingurutik, ez bakarrik Diskurtsoa-rekiko baizik eta Erregelak-ekiko ere bai. Geometria-k bi idazlan horiekin ditu loturak. Zientzia, Descartes-en eskutik ez da zatitua agertzen, ordena eta jarraipen jakin batekin baizik.

Zergatik bada, Descartes-i buruzko dagoen literatura guztian, egiten da hainbat komeria batetik fisika eta bestetik metafisika, Descartes enpirista, matematika eta metafisika azaltzeko? eta hainbat eta hainbat esamolde. Descantes, bat bakarra da, eta beste komeria guztiak, gure subjektibitateak eragindakoak dira, ez Descartes-ek. Descartes ez da mozorrotzen, nahiz etakontrakoak ere entzuten ditugun, Descartes-ek cogitoa aldarrikatzen du, eta hau da bere printzipion. Gainontzeko guztia sasi-diskurtsoak dira Husserl-ek dioskun bezala. Diskurtso hauck agerian uzten dutena gure ahulczia da, Deskartes-ek maiz uzten du arrazoiaren eskuetan gure bidea:

Ez naiz, ere harro agertzen batzuen (irizziak) lehen asmatzaile jzateaz, baizik inoiz neretzat (iriziak) hartu ez izanaz, bestek esandakoak izan direlako edo ala esanak izan ez direlako, baizik bere egiaz arrazoiak ohartarazi nauelako soilik. 12

Eta arrazoiak erakusten ere dio zein hizkuntzatan idatzi behar duen bere Diskuntson. Eta hau gaur, hemen, kongresu honetan, aipatzea oso gauza baikorra da. Guk hemen, Euskal Herriko Unibertsitatea deritzon honetan, gure hizkuntza lau haizetara hedatzeko parada dugu.

Deskartes-en kasuan ekintza iraultzailetzat jo daiteke, bere garaian ekintza honek ausardia esan nahi zuelako:

Eta frantsesez idazten badut, nere herriko hizkuntza dena, eta ez latinez, nere arau-emaileena dena, nere iritziak, liburu zaharretan besterik sinesten ez duten haiek, euren arrazoi natural hutsaz bakarrik baliatzen diren beste hajek baino hobeto juzkatuko dituztelakoan nagoslako da. ${ }^{13}$

II Aristotele, Metofisika, 982 b, 11-32 Gredos

12 Descartes, Renć, Discours de la mëlhode: Intsoduction et notes, E.Gilson, Paris: Vrin, 1979, 145. orr.

13 Op. cit., 144-145 ort. 
Arrazoiaren baieztapena azaltzen digu berriz ere Descartes-ek. Arrazoia, jakintzaren orokortasuna goraipatzeko. Hastapeneko jakintza, ez zatitutakoa, gaur egun betierekotzen ari dena. Amaierako aipanen bat: gure hezkuntza sisteman Descartes-en proicktua bertan behera geratu da. Bere asmoa, zientzia finkatzea, beste garai baterako gelditzen da; gure ikasleak era honetara bideratzen ari dira: filosofo batek ez ditu Geometria-ren bideak ikusten, eta matematikoa ere, ez da Diskuntso-aren onto-metodoaz jabetzen.

José Bergamin-ek esan zuen "existir es pensar, y pensar es comprometerse". Beraz, gure pentsamenduen konpromezuak, Filosofia eta ez filosofiak craikitzea behar du izan. 